\title{
Category Norms for Korean Adults Age 55 to 74
}

\author{
JungWan Kimª, Yeonwook Kang ${ }^{\mathrm{b}}$, Ji Hye Yoon \\ ${ }^{a}$ Department of Speech Pathology, Daegu University, Gyeongsan, Korea \\ ${ }^{b}$ Department of Psychology, Hallym University, Chuncheon, Korea \\ 'Department of Speech Pathology and Audiology, Audiology \& Speech Pathology Research Institute, Hallym University, Chuncheon, Korea
}

\author{
Correspondence: Ji Hye Yoon, $\mathrm{PhD}$ \\ Department of Speech Pathology and Audiology, \\ Hallym University, 1 Hallymdaehak-gil, \\ Chuncheon 24252, Korea \\ Tel: $+82-33-248-2224$ \\ Fax: +82-33-256-3420 \\ E-mail: j.yoon@hallym.ac.kr
}

Received: October 5, 2015

Revised: November 13, 2015

Accepted: December 2, 2015

This work was supported by the National Research Foundation of Korea grant funded by the Korean government (NRF-2014S1A5A2A03065709).

\begin{abstract}
Objectives: This study seeks to provide preliminary data on the production frequency and typicality of noun exemplars by semantic category for Korean adults age 55 to 74. Methods: A total of 401 individuals participated in the study. The study was divided into two parts. In experiment $1(\mathrm{~N}=220)$, the subjects were given generative naming tasks from ten categories: clothing, kitchen utensils, personal belongings, vegetables, furniture, transportation, school supplies, electronic devices, flowers, and animals. In experiment $2(\mathrm{~N}=216)$, the mean number of production and number of different words of noun exemplars were evaluated. The semantic typicality of each noun exemplar obtained from experiment 1 was also rated. Results: The category of items in fluency tasks, along with age and gender has a distinctive influence on the semantic networks of adults age 55 to 74 . Conclusion: Our findings suggest that age-specific Korean category norms and data for semantic typicality are needed. In addition, these results are clinically meaningful given that they provide preliminary data to select stimuli item for naming treatment programs of patients with neurogenic language disorders. This study also provides a basis for future study on the internal structure of semantic networks in Korean adults and the efficacy of semantic feature analysis in naming treatment.
\end{abstract}

Keywords: Naming, Normal aging, Category norm, Exemplars, Typicality 통제단어연상검사(controlled oral word association test, COWAT; Lucas et al., 1998)는 범주화 지식과 구조를 활용하여 언어와 연관된 인지기능을 검사하는 방법 중 가장 보편적으로 사용되는 평가 방법이다(Chung, Hwang, \& Hong, 2014). 제한된 시간 내에 특정 범주에 속하는 단어를 자발적으로 떠올려야 하므로, 사고의 생산성을 평가하는 전두엽/실행기능 검사로 많이 사용되고 있다. 따라서 전두엽 기능이 저하된 치매 환자의 언어기능을 평가하거나 (Crossley, D’Arcy, \& Rawson, 1997; Henry \& Crawford, 2004) 뇌손 상으로 인해 범주-특정적 손상을 보이는 실어증 환자에 대한 연구 (Forde, 1999) 등에서 이 검사를 통해 특정 범주에 대한 개별 언어의 의미 지식 구조를 확인한다(Gõni et al., 2011; Kim \& Kim, 2012).

실어증, 외상성 뇌손상, 퇴행성 치매 환자 등을 포함한 신경언어 장애 환자들의 경우, 의미체계의 손상으로 인해 다양한 중증도에 걸쳐 이름대기 장애를 보이게 된다. 이때 적용할 수 있는 여러 가지 이름대기 치료 중, 의미체계를 강화하는 이름대기 중재 접근법에서 의미전형성(semantic typicality) (Kiran \& Thompson, 2003)이라 는 개념을 도입하면서 인간이 갖고 있는 의미 지식의 구조가 어떻 게 구성되어 있는지 연구하게 되었다.

의미전형성이란, 의미 범주 내에 속해 있는 본보기(exemplars)가 그 의미 범주를 대표하는 정도, 즉 전형적인 의미자질(semantic feature)을 어느 정도 갖고 있는가에 관한 지표이다(Kiran \& Thompson, 2003). 여기서 우리는 '범주'와 '전형성'에 대해 명확히 정의할 필요가 있는데, 이는 이 두 가지 요소가 어휘 습득 과정(Rosch \& Mervis, 1975)이나 어휘 산출 시 의미망(semantic network)의 어휘 간 연결 정도(Kim, 2010; Kiran, 2008)에 영향을 미치는 것으로 보 고되고 있기 때문이다. 가령, '개'는 상위 범주로 '동물' 또는 '가축' 으로 불릴 수 있고, ‘마르티스, '요크셔 테리어'와 같이 좀 더 구체적 인 하위 범주로 불릴 수도 있다. 일반적으로 '개'와 같은 기본사물 수준(basic object level) 또는 중간 수준이 빈번히 사용되며, 가장 쉽게 범주 상호 간의 구별을 가능하게 하므로 어휘 습득 과정에서 
도 일찍 습득되는 것으로 본다(Rosch \& Mervis, 1975).

범주에 대한 개념과 의미 연결망 모델을 연관지어 설명해 보면, 동물 범주에 대한 통제단어연상검사 시, '참새, 비둘기, 사자, 하이에 나, 개, 고양이'와 같은 반응을 보였다면, '참새, 비둘기'는 조류, '사 자, 하이에나'는 야생 동물, '개, 고양이'는 네 발 달린 동물(가축)이 라는 하위 범주로 분류할 수 있을 것이다. 이때 하위 범주 내의 동 물들 간에는 유사도가 높게 나타나며, 이는 머릿속 사전에서 이 본 보기들을 비슷한 범주로 인식하고 있고, 공통 속성을 지닌 개념으 로 보기 때문에 다른 하위 범주 내의 개념들보다 더 강하게 연결되 어 있다고 볼 수 있다(Collins \& Loftus, 1975). 어떤 본보기가 그 범 주에 포함될지의 여부를 결정하기 위해서는 해당 본보기가 그 범주 의 원형에 얼마나 가까운지, 즉 얼마나 전형적인지를 고려해야 한 다. 동물에 대한 통제단어연상검사를 통해 동물을 8 개의 하위 범주 로 나누고, 산출된 빈도수 50 위까지의 본보기의 전형성을 조사한 국내 연구에서는 하위 범주 중, '가축' 범주가 가장 전형성이 높은 것으로 나타났고, '곤충' 범주가 가장 비전형적인 것으로 나타났다 (Kim \& Kim, 2012). 이러한 전형성에 대한 논의는 전형성이 언어적 기억력이나 어휘 인출 등의 다양한 인지 처리에 미치는 영향력을 살펴본 여러 연구들에서 이루어져 왔는데, 기억하여야 할 단어나 문장 내 포함된 단어들의 범주 전형성이 높을수록 기억 수행이 더 욱 좋아지는 것으로 나타났다(Hasselhorn, 1992). 또한 범주 판단 과제(category verification task)에서도 전형성이 높은 본보기에서 청장년층의 반응 시간(response time)이 빨라지는 것으로 보고되 었다(Kiran \& Thompson, 2003). 그러나, 신경언어장애 환자들을 대상으로 전형적인 본보기와 비전형적인 본보기로 구분하여 이름 대기 중재 효과를 살펴본 연구에서는 비전형적인 본보기를 사용한 어휘 인출 훈련이 훈련되지 않은 항목으로의 일반화를 더 효율적 으로 촉진시킬 수 있는 것으로 나타났다. 이 결과는 가장 전형적인 본보기, 즉 개념적으로 친숙도 높은(Hampton \& Gardiner, 1983) 어휘를 먼저 훈련하는 것이 이름대기 중재 일반화에 더 긍정적인 영향을 미치는 것은 아님을 시사한다.

이처럼 어휘가 속한 범주와 그 어휘의 범주 내 전형성 수준이 여 러 심리언어학적 과제 수행에 미치는 영향력을 고려해 본다면, 신경 언어장애 환자를 대상으로 한 이름대기 중재 시 의미 범주에 대한 구분과 본보기의 전형성 요소는 치료자극을 선정하는 데 있어 매 우 중요하게 고려되어야 할 것이다. 또한 연령에 따라 사회문화적 경험과 배경 지식, 사용 어휘가 달라지므로 명사 범주 내에서도 각 연령대별로 인출 요구도가 높은 어휘가 다를 수 있을 것이다. 따라 서 성인 집단 내에서 언어장애를 경험할 가능성이 가장 높은 연령 대가 50-70대인 점을 고려해 본다면(Im et al., 2011) 비교 기준으로
서 해당 연령대 정상 성인들의 생성 어휘에 대한 성별 및 연령에 따 른 차이를 확인하고 치료 자극 선정에 사용될 수 있는 어휘 목록 역 시 확보되어야 한다.

본 연구는 성인 신경언어장애 환자군의 이름대기 중재를 위한 언 어재활 프로그램의 기초자료를 확보하기 위해서 55-74세 정상 성 인의 명사 범주별 어휘 본보기 목록을 파악하고자 수행되었다. 이 를 위해, 연구는 2 단계로 나누어 시행되었으며, 1 단계에서는 총 10 개 명사 범주에 대한 통제단어연상검사를 실시하여 명사 범주별 본 보기의 평균 반응수와 본보기 종류의 총수를 산출하였고, 2 단계에 서는 각 범주별 상위 30 위까지의 본보기들에 대한 의미전형성을 평 정하였다. 본 연구는 한림대학교 임상연구윤리위원회의 승인 (HIRB-2015-013)을 받았다.

\section{연구 방법}

\section{연구대상}

서울, 경기, 강원, 대구, 경북 지역에 거주하는 55세부터 74 세까지 총 401 명의 정상 성인들이 본 연구에 참여하였다. 모든 연구 대상자 들에게 인지기능에 영향을 미칠 수 있는 병력에 관하여 질문하는 건강선별설문(Christensen, Multhaup, Nordstrom, \& Voss, 1991) 과 한국판 간이정신상태 검사(Korean-Mini Mental State Examination, K-MMSE; Kang, 2006)를 실시하여 질환이 없고 정상적인 인지기능을 갖고 있는 것으로 확인된 사람들만을 선별하였다. 연 구는 두 단계로 나뉘어 수행되었고 각 단계별 연구대상자의 인구학 적 특성은 다음과같다.

\section{1단계 연구(10개 명사 범주별 통제단어연상검사 시행) 참여자}

1 단계 연구에 참여한 대상자는 총 220 명이다(Table 1). 연령집단 간 성별분포, 교육 연수, $\mathrm{K}-\mathrm{MMSE}$ 점수에 대한 동질성 검정 결과, 성별은 유의한 차이가 없었으나 $\left(\chi^{2}=.42, p>.05\right)$, 교육 연수 $(F=7.31$, $p<.001)$ 와 K-MMSE 점수 $(F=3.55, p<.05)$ 에서 유의한 차이가 있 는 것으로 나타났다. Bonferroni 사후검정 결과, 교육수준은 70-74

Table 1. Experiment 1: Demographic information of the participants

\begin{tabular}{lcccc}
\hline Age $(\mathrm{yr})$ & $\mathrm{N}$ & Sex $(\mathrm{M}: \mathrm{F})$ & Level of education (yr) & K-MMSE \\
\hline $55-59$ & 63 & $29: 34$ & $12.10(3.13)$ & $28.95(.99)$ \\
$60-64$ & 54 & $27: 27$ & $10.67(3.40)$ & $28.30(1.11)$ \\
$65-69$ & 52 & $27: 25$ & $11.29(3.39)$ & $28.60(1.11)$ \\
$70-74$ & 51 & $25: 26$ & $9.37(2.68)$ & $27.92(1.18)$ \\
Total & 220 & $108: 112$ & $10.92(3.30)$ & $28.47(1.15)$ \\
\hline
\end{tabular}

Values are presented as mean (SD).

K-MMSE= Korean-Mini Mental State Examination (Kang, 2006) 
Table 2. Experiment 2: Demographic information of the participants

\begin{tabular}{lcccc}
\hline Age $(y r)$ & $N$ & Sex (M:F) & Level of education (yr) & K-MMSE \\
\hline $55-59$ & 54 & $27: 27$ & $9.46(3.18)$ & $28.80(1.12)$ \\
$60-64$ & 54 & $27: 27$ & $9.39(2.99)$ & $28.37(1.12)$ \\
$65-69$ & 54 & $27: 27$ & $9.44(3.17)$ & $28.28(1.16)$ \\
$70-74$ & 54 & $28: 26$ & $9.24(2.93)$ & $27.85(1.12)$ \\
Total & 216 & $109: 107$ & $9.38(3.05)$ & $28.32(1.17)$ \\
\hline
\end{tabular}

Values are presented as mean (SD).

K-MMSE = Korean-Mini Mental State Examination (Kang, 2006).

세 집단이 65-69세 집단에 비해 유의하게 낮았고, K-MMSE 점수는 70-74세 집단이 55-59세 집단에 비해 유의하게 낮았다.

\section{2단계 연구(의미전형성 평정 과제) 참여자}

2단계 연구에는 총 216 명(1단계 연구 참여자 35명, 새로운 참여자 181 명)의 피험자가 참여하였다(Table 2). 집단 간 성별분포, 교육 연 수, $\mathrm{K}-\mathrm{MMSE}$ 점수에 대한 동질성 검정 결과, 성별 $\left(\chi^{2}=.06, p>.05\right)$ 과 교육 연수 $(F=.06, p>.05)$ 는 차이가 없었으나 K-MMSE 점수 $(F=6.34, p<.001)$ 에서 집단 간 유의한 차이가 있는 것으로 나타났 다. Bonferroni 사후검정 결과, K-MMSE 점수는 70-74세 집단이 55-59세에 비해 유의하게 낮은 것으로 나타났다.

\section{연구절차}

1 단계 연구에서는 우선 참여자에게 제시할 통제단어연상검사의 범주를 선정하였다. 우리말 범주수준과 전형성에 대해 조사한 국 내 연구들을 참고하여(Jeun \& Kang, 2007; Rhee, 1991; Sung, Mo, Lee, \& Sim, 2014) 전문가 집단(언어병리학과 교수 2 인, 심리학과 교 수 1 인)의 논의를 거쳐 일상생활에서 가장 중요하다고 생각되는 범 주 10 개(옷, 주방용품, 소지품, 채소, 가구, 교통수단, 학용품, 전자 제품, 꽃, 동물)를 선정하였다. 각 범주별로 의미복잡성의 차이가 있 을 수 있고, 무한정 시간을 제공할 경우 검사자 변인이 개입될 소지 가 있으므로 검사 시에는 통제단어연상검사 규칙을 그대로 적용하 여 각 범주별로 동일하게 1 분간 실시하였다.

수집된 자료는 언어병리학자와 신경심리학자가 함께 검토하고 정반응과 오반응으로 분류한 후 오반응을 자료에서 제외하였고 중 복된 반응은 1 회만 산정하였다(예: [꽃] 범주에서 '봉숭아', '봉선 화'). 단, 방언(예: [부억용품] 범주에서 '재까락'(=젓가락))은 정반 응으로 간주하여 반응수에 포함시켰다. 그 후, 각 범주별 평균 반응 수와 어휘 다양도를 살펴볼 수 있는 서로 다른 본보기 종류의 총수 를 산출하였다.

2 단계 연구에서는 각 범주의 본보기별 빈도수를 가장 높은 순위 부터 낮은 순위로 범주별로 정리한 후, 각 범주 당 1 위에서 30 위까
지의 본보기에 대한 의미전형성 평정을 실시하였다. Rosch (1973) 가 제시한 바와 동일한 방식으로, 각 범주별 30 개씩 총 300 개의 어 휘 본보기에 대해 1점(가장 전형적인, 'most typical')부터 7점(비전 형적인, 'least typical and very poor example')까지 평정하도록 하 였다. 설문을 시작하기 전, 예시로 '개구리'를 제시한 후, '개구리'는 친숙도가 높지만, 동물 범주를 대표하는 어휘 본보기로는 '전형적 이지 않을 수도 있음을 설명하였다. 전형성 평정에 사용되지 않은 어휘 본보기들 중에 '알로에([채소] 범주)'와 ‘휠체어([교통수단] 범 주)'를 예로 들어 평정 연습을 다시 실시하였다. 제시되는 순위에 따 른 영향을 배제하기 위하여 각 범주의 본보기는 순위와 관계없이 가나다순으로 참여자에게 제시하였다. 범주별로 산출된 30 위까지 의 본보기는 Appendix 1에 포함되어 있다.

\section{연구 결과}

\section{명사 범주별 본보기 산출빈도}

10 개 명사 범주별 평균 반응수와 본보기 종류의 총수를 산출한 결과는 Table 3 과 같다. 범주별로 산출된 전체 본보기의 목록과 각 본보기의 산출빈도는 Appendix 1에 제시되어 있다.

본 연구는 성별, 연령 등에 따른 어휘 본보기와 전형성의 기초자 료를 파악하기 위한 것이므로 언어검사 수행에 미치는 교육 연수 차이의 영향력을 좀 더 배제시키기 위해 이를 공변량으로 처리하였 다. 공변량 처리 후, 연령에 따른 각 범주별 평균 반응수를 비교한 결과는 Table 4 와 같다. 이 중에서 연령 집단 간 공통적인 양상을 보 인 범주가 관찰되었는데, 옷과 꽃 범주는 70-74세 집단이 나머지 세 연령집단에 비하여 유의하게 낮은 반응수를 보였다. 교통수단과 학용품 범주는 55-59세 집단이 나머지 세 연령집단에 비하여 유의 하게 높은 반응수를 보였다.

교육 연수를 공변량으로 처리하고 난 후, 성별에 따른 각 범주별 반응 수를 비교한 결과, 옷, 주방용품, 소지품, 채소, 가구 범주에서 여성이 남성보다 유의미하게 높은 평균 반응수를 보였다. 교통수 단, 학용품, 전자제품, 꽃, 동물 범주에서는 성별 간 유의한 차이가 관찰되지 않았다(Table 5).

\section{의미전형성 평정 결과}

10 개 범주별 각 본보기의 의미전형성에 대한 평정은 7점 척도로 이루어졌으며, 이러한 평정 점수의 범주 간 표준화를 위해 각 범주 별 본보기에 대한 의미전형성을 표준화 점수(z-score)로 Appendix 2에 제시하였다. 
Table 3. Mean number of production and number of different words (NDW) of exemplars by semantic category

\begin{tabular}{|c|c|c|c|c|c|c|c|c|c|}
\hline Category & Age (yr) & Sex & Mean (SD) & NDW & Category & Age (yr) & Sex & Mean (SD) & NDW \\
\hline \multirow[t]{12}{*}{ Clothing } & \multirow[t]{3}{*}{$55-59$} & $M$ & $10.62(2.43)$ & 71 & \multirow[t]{12}{*}{ Transportation } & \multirow[t]{3}{*}{$55-59$} & $M$ & $9.59(2.84)$ & 57 \\
\hline & & $\mathrm{F}$ & $11.11(2.79)$ & 65 & & & $\mathrm{~F}$ & $8.82(2.72)$ & 46 \\
\hline & & Total & $10.88(2.62)$ & 88 & & & Total & $9.17(2.78)$ & 70 \\
\hline & \multirow[t]{3}{*}{$60-64$} & $\mathrm{M}$ & $9.63(2.24)$ & 58 & & \multirow[t]{3}{*}{$60-64$} & $\mathrm{M}$ & $7.59(1.67)$ & 27 \\
\hline & & $\mathrm{F}$ & $11.11(2.12)$ & 63 & & & $\mathrm{~F}$ & $7.52(1.87)$ & 32 \\
\hline & & Total & $10.37(2.28)$ & 78 & & & Total & 7.56 (1.76) & 40 \\
\hline & \multirow[t]{3}{*}{$65-69$} & M & $10.41(2.55)$ & 61 & & \multirow[t]{3}{*}{$65-69$} & $\mathrm{M}$ & 7.70 (2.07) & 34 \\
\hline & & $\mathrm{F}$ & $11.12(2.52)$ & 56 & & & $\mathrm{~F}$ & $7.76(2.11)$ & 33 \\
\hline & & Total & $10.75(2.54)$ & 79 & & & Total & $7.73(2.07)$ & 43 \\
\hline & \multirow[t]{3}{*}{$70-74$} & M & $8.36(1.87)$ & 40 & & \multirow[t]{3}{*}{$70-74$} & $\mathrm{M}$ & $6.96(1.67)$ & 25 \\
\hline & & $\mathrm{F}$ & $8.81(2.53)$ & 50 & & & $\mathrm{~F}$ & $6.92(1.77)$ & 31 \\
\hline & & Total & $8.59(2.22)$ & 55 & & & Total & $6.94(1.70)$ & 40 \\
\hline \multirow{12}{*}{ Kitchen utensils } & \multirow[t]{3}{*}{$55-59$} & $\mathrm{M}$ & 12.03 (3.25) & 67 & \multirow{12}{*}{ School supplies } & $55-59$ & $\mathrm{M}$ & 10.86 (3.76) & 60 \\
\hline & & $\mathrm{F}$ & $12.94(4.31)$ & 89 & & & $\mathrm{~F}$ & $10.18(3.70)$ & 56 \\
\hline & & Total & 12.52 (3.85) & 106 & & & Total & $10.49(3.71)$ & 73 \\
\hline & $60-64$ & $\mathrm{M}$ & 9.78 (2.98) & 59 & & $60-64$ & $M$ & $8.70(2.52)$ & 50 \\
\hline & & $\mathrm{F}$ & 11.37 (2.91) & 67 & & & $\mathrm{~F}$ & $8.22(2.58)$ & 40 \\
\hline & & Total & $10.57(3.01)$ & 83 & & & Total & $8.46(2.53)$ & 59 \\
\hline & $65-69$ & M & $9.78(2.61)$ & 62 & & $65-69$ & M & $8.15(3.01)$ & 42 \\
\hline & & $\mathrm{F}$ & $11.08(1.96)$ & 66 & & & $\mathrm{~F}$ & $8.52(2.12)$ & 36 \\
\hline & & Total & $10.40(2.39)$ & 83 & & & Total & $8.33(2.60)$ & 49 \\
\hline & $70-74$ & M & $8.72(1.97)$ & 56 & & $70-74$ & M & $8.04(3.05)$ & 36 \\
\hline & & $F$ & $8.31(2.86)$ & 44 & & & $\mathrm{~F}$ & $6.42(2.30)$ & 29 \\
\hline & & Total & $8.51(2.44)$ & 63 & & & Total & $7.22(2.79)$ & 41 \\
\hline Personal belongings & $55-59$ & M & $9.04(2.93)$ & 59 & Electronic devices & $55-59$ & M & $10.52(2.63)$ & 60 \\
\hline & & $\mathrm{F}$ & $10.26(2.51)$ & 66 & & & $\mathrm{~F}$ & $10.35(2.73)$ & 66 \\
\hline & & Total & $9.65(2.77)$ & 83 & & & Total & $10.43(2.66)$ & 77 \\
\hline & $60-64$ & M & $6.56(1.76)$ & 36 & & $60-64$ & $\mathrm{M}$ & $9.70(2.91)$ & 55 \\
\hline & & $\mathrm{F}$ & $8.37(2.20)$ & 52 & & & $\mathrm{~F}$ & $9.37(2.66)$ & 51 \\
\hline & & Total & 7.46 (2.18) & 64 & & & Total & $9.54(2.77)$ & 69 \\
\hline & $65-69$ & $\mathrm{M}$ & $7.30(2.11)$ & 51 & & $65-69$ & M & $8.81(2.66)$ & 55 \\
\hline & & $\mathrm{F}$ & 8.48 (2.49) & 63 & & & $\mathrm{~F}$ & $8.32(1.73)$ & 44 \\
\hline & & Total & 7.89 (2.36) & 82 & & & Total & $8.58(2.25)$ & 62 \\
\hline & $70-74$ & $M$ & 8.68 (3.65) & 64 & & $70-74$ & M & $6.88(1.92)$ & 37 \\
\hline & & $\mathrm{F}$ & $8.08(2.45)$ & 53 & & & $\mathrm{~F}$ & $6.46(2.35)$ & 40 \\
\hline & & Total & 8.39 (3.12) & 81 & & & Total & $6.67(2.14)$ & 51 \\
\hline Vegetables & $55-59$ & M & 10.62 (3.35) & 50 & Flowers & $55-59$ & $M$ & 10.69 (3.01) & 71 \\
\hline & & $\mathrm{F}$ & 13.12 (3.24) & 69 & & & $\mathrm{~F}$ & 11.68 (3.81) & 80 \\
\hline & & Total & $11.97(3.50)$ & 70 & & & Total & $11.24(3.48)$ & 103 \\
\hline & $60-64$ & M & 11.04 (3.33) & 58 & & $60-64$ & $M$ & $10.11(3.07)$ & 59 \\
\hline & & $\mathrm{F}$ & 12.37 (3.35) & 52 & & & $\mathrm{~F}$ & $10.41(2.79)$ & 58 \\
\hline & & Total & 11.70 (3.38) & 70 & & & Total & $10.26(2.91)$ & 77 \\
\hline & $65-69$ & M & 10.33 (3.33) & 58 & & $65-69$ & $M$ & $10.37(3.16)$ & 68 \\
\hline & & $\mathrm{F}$ & 11.24 (1.92) & 59 & & & $\mathrm{~F}$ & $10.48(2.06)$ & 65 \\
\hline & & Total & $10.77(2.76)$ & 72 & & & Total & $10.42(2.67)$ & 85 \\
\hline & $70-74$ & $M$ & 8.64 (2.18) & 39 & & $70-74$ & $M$ & 9.28 (2.28) & 58 \\
\hline & & $\mathrm{F}$ & 10.46 (3.02) & 50 & & & $\mathrm{~F}$ & $7.81(2.70)$ & 50 \\
\hline & & Total & $9.57(2.77)$ & 55 & & & Total & $8.53(2.59)$ & 73 \\
\hline Furniture & $55-59$ & $M$ & $8.41(2.16)$ & 41 & Animals & $55-59$ & $\mathrm{M}$ & $17.10(4.59)$ & 87 \\
\hline & & $\mathrm{F}$ & 9.24 (2.50) & 34 & & & $\mathrm{~F}$ & $14.62(4.41)$ & 78 \\
\hline & & Total & 8.86 (2.37) & 46 & & & Total & $15.76(4.63)$ & 101 \\
\hline & $60-64$ & $\mathrm{M}$ & 8.07 (2.34) & 29 & & $60-64$ & $M$ & $14.04(2.85)$ & 71 \\
\hline & & $\mathrm{F}$ & 8.07 (2.06) & 28 & & & $\mathrm{~F}$ & 13.54 (3.50) & 65 \\
\hline & & Total & 8.07 (2.18) & 34 & & & Total & 13.79 (3.18) & 85 \\
\hline & $65-69$ & $M$ & 7.37 (1.78) & 29 & & $65-69$ & M & 13.96 (3.61) & 67 \\
\hline & & $\mathrm{F}$ & 7.84 (1.60) & 25 & & & $\mathrm{~F}$ & 13.04 (1.99) & 65 \\
\hline & & Total & $7.60(1.70)$ & 33 & & & Total & $13.52(2.95)$ & 86 \\
\hline & $70-74$ & $M$ & 6.60 (1.89) & 26 & & $70-74$ & $\mathrm{M}$ & $11.68(2.75)$ & 50 \\
\hline & & $\mathrm{F}$ & 6.96 (2.39) & 25 & & & $\mathrm{~F}$ & $11.62(2.95)$ & 59 \\
\hline & & Total & $6.78(2.15)$ & 31 & & & Total & $11.65(2.83)$ & 73 \\
\hline & & & & & Total & & & $9.69(3.45)$ & 111.7 \\
\hline
\end{tabular}


Table 4. Mean number of production by age groups

\begin{tabular}{lrrl}
\hline & \multicolumn{1}{c}{ Total } & \multicolumn{1}{c}{$F$} & \multicolumn{1}{c}{ Post-hoc } \\
\hline Clothing & $10.19(2.57)$ & $8.69^{* * *}$ & $\mathrm{a}=\mathrm{b}=\mathrm{c}>\mathrm{d}$ \\
Kitchen utensils & $10.61(3.33)$ & $13.70^{* * *}$ & $\mathrm{a}>\mathrm{b}=\mathrm{c}>\mathrm{d}$ \\
Personal belongings & $8.35(2.73)$ & $6.98^{* * *}$ & $\mathrm{a}=\mathrm{d}, \mathrm{b}=\mathrm{c}=\mathrm{d}, \mathrm{a}>\mathrm{b}=\mathrm{c}$ \\
Vegetables & $11.06(3.25)$ & $4.98^{* *}$ & $\mathrm{a}=\mathrm{b}=\mathrm{c}, \mathrm{a}=\mathrm{b}>\mathrm{d}, \mathrm{c}=\mathrm{d}$ \\
Furniture & $7.88(2.24)$ & $6.37^{* * *}$ & $\mathrm{a}=\mathrm{b}>\mathrm{d}, \mathrm{b}=\mathrm{c}, \mathrm{a}>\mathrm{c}=\mathrm{d}$ \\
Transportation & $7.91(2.30)$ & $8.87^{* * *}$ & $\mathrm{a}>\mathrm{b}=\mathrm{c}=\mathrm{d}$ \\
School supplies & $8.72(3.21)$ & $9.90^{* * *}$ & $\mathrm{a}>\mathrm{b}=\mathrm{c}=\mathrm{d}$ \\
Electronic devices & $8.90(2.83)$ & $17.36^{* * *}$ & $\mathrm{a}=\mathrm{b}, \mathrm{b}=\mathrm{c}, \mathrm{a}>\mathrm{c}>\mathrm{d}$ \\
Flowers & $10.17(3.10)$ & $5.70^{* *}$ & $\mathrm{a}=\mathrm{b}=\mathrm{c}>\mathrm{d}$ \\
Animals & $13.79(3.81)$ & $8.64^{* * *}$ & $\mathrm{a}=\mathrm{b}, \mathrm{a}>\mathrm{c}, \mathrm{b}=\mathrm{c}=\mathrm{d}$
\end{tabular}

Values are presented as mean (SD).

Age group: $a=55-59 \mathrm{yr} ; b=60-64 \mathrm{yr} ; c=65-69 \mathrm{yr} ; d=70-74 \mathrm{yr}$.

${ }^{*} p<.05,{ }^{* *} p<.01,{ }^{* * *} p<.001$.

\section{논의 및 결론}

통제단어연상검사는 외상성 뇌손상, 우울증, 알츠하이머병, 조현 병, 자폐증에 이르기까지 여러 유형의 대상자들의 언어 및 실행통 제과정(executive control process)을 평가할 수 있다는 점에서 다양 하게 실시되어 오고 있다. 간단한 방법으로도 이 과제를 해결하는 데 수반되는 신경 체계에 대한 설명이 가능하다는 점에서(Birn et al., 2010) 이름대기 중재를 위한 언어재활 프로그램 구성에서도 매 우 중요하게 고려되는 과제라고 할 수 있다. 따라서 본 연구에서는 신경언어장애 환자군과 위험군의 이름대기 중재를 위한 기초자료 를 확보하기 위한 목적으로 일상생활에서 자주 사용되는 명사 범 주들에 대한 본보기 산출빈도(범주별 평균 반응수와 본보기 종류 의 수)와 전형성에 대한 조사를 실시하였다.

전통적으로 범주 유창성 과제는 생성한 전체 단어의 수를 측정 하는 것이 일반적이었다. 그러나, 지난 몇 년에 걸쳐 개개 반응의 구 성이 어떻게 이루어져 있는지 군집(cluster)을 살펴봄으로써(Ventura, Morais, \& Kolinsky, 2005) 이 과제를 통해서 의미적 하위범주 에 대한 기억을 탐색할 수 있는 능력을 측정하려는 시도가 이루어 져 왔고, 최근 들어서는 시각과 청각을 통해 입력된 단어, 사물이나 현상, 행위 등을 명확하게 인식하고 이해하는 데 사용되는 총체적 인 지식인 의미지식(semantic knowledge)을 평가하여 중재 프로그 램에 적용하기 위한 다양한 시도가 이루어지고 있다. 의미연결망 (semantic network)은 성별, 교육수준, 연령의 영향을 받기 때문에 범주 유창성 과제에서 나타난 본보기의 빈도수와 전형성 평정 등 은 연령 집단이나 교육 집단의 차이에 따라 민감하게 달라질 수 있 다. 본 연구를 통해서도 50-70대 성인들의 의미 네트워크는 범주 유 창성 과제의 범주 목록에 따라, 연령, 성별에 따라 변별적으로 달라
Table 5. Mean number of production by gender

\begin{tabular}{lccc}
\hline Category & Male $(\mathrm{N}=108)$ & Female $(\mathrm{N}=112)$ & \multicolumn{1}{c}{$F$} \\
\hline Clothing & $9.80(2.43)$ & $10.58(2.67)$ & $10.13^{* * *}$ \\
Kitchen utensils & $10.14(3.00)$ & $11.04(3.59)$ & $9.75^{* * *}$ \\
Personal belongings & $7.90(2.87)$ & $8.80(2.53)$ & $6.03^{*}$ \\
Vegetables & $10.19(3.19)$ & $11.90(3.11)$ & $29.65^{* * *}$ \\
Furniture & $7.65(2.15)$ & $8.12(2.32)$ & $10.95^{* *}$ \\
Transportations & $8.01(2.33)$ & $7.83(2.28)$ & .18 \\
School supplies & $9.09(3.30)$ & $8.65(3.13)$ & .01 \\
Electronic devices & $9.05(2.87)$ & $8.76(2.81)$ & 1.38 \\
Flowers & $10.14(2.92)$ & $10.21(3.28)$ & 1.68 \\
Animals & $14.32(4.02)$ & $13.29(3.56)$ & .27 \\
\hline
\end{tabular}

Values are presented as mean (SD).

${ }^{*} p<.05,{ }^{* *} p<.01,{ }^{* * *} p<.001$.

짐을 확인할 수 있었다.

1 단계 연구의 분석 결과를 살펴보면, 10 개 범주에 따라 연구대상 자의 반응이 여러 측면에서 매우 다름을 알 수 있다. 연령을 기준으 로 하였을 때, 55-59세 집단의 경우, 10 개 범주 모두에서 평균 반응 수가 8개 이상이었던 반면, 60-64세 집단은 '교통수단', '소지품' 범 주에서 평균 반응수가 8개 미만인 것으로 나타났고, 65-69세 집단 은 '교통수단', '소지품' '가구' 범주에서, 70-74세 집단은 '교통수단', '학용품' '전자제품', '가구' 범주에서 평균 반응수가 8개 미만인 것 으로 나타나 연령이 증가할수록 단어 인출 개수가 줄어드는 범주 의 수가 증가하는 양상을 보였다. 이는 연령이 증가함에 따라 해당 범주 본보기들에 대한 의미적 활성화가 보다 어려워짐을 의미하는 것이라 해석할 수 있다. 또한 ‘채소', ‘꽃’을 제외한 나머지 7개 범주 에서 본보기 종류의 총수가 연령이 증가함에 따라 감소하는 양상 을 보였는데, 이렇게 평균 반응수와 본보기 종류의 총수가 비례적 으로 감소하는 것은 젊은 연령대 성인일수록 이 범주의 본보기들 에 대한 많은 지식을 갖고 있으나 연령이 증가할수록 그 지식이 감 소된다고 볼 수 있다. 그러나, ‘채소, '꽃' 범주는 연령의 영향을 받지 않는 것으로 밝혀진 바 이들 범주는 연령이 미치는 영향이 매우 제 한적인 것으로 생각되며 이름대기 중재를 위한 범주를 결정할 때 이런 사실이 고려되어야 할 것이다. 또한, 25 년 전 480 명의 청년층 을 대상으로 30 초간 범주별 생성 이름대기를 실시하여 그 결과를 보고한 Rhee (1991)의 연구와 비교하면, 본 연구에서는 중년층과 노년층을 대상으로 범주별로 1 분간 검사를 실시하여, 검사 제한 시 간이 2 배로 길었음에도 불구하고 '채소' 범주를 제외하고는 중년층 과 노년층의 평균 반응수와 본보기 종류의 총수가 적었다. 이는 통 제단어연상검사에서 확인할 수 있는 구어 및 실행통제과정이 연령 요인의 영향을 많이 받는다는 것을 시사한다.

성별에 따른 차이도 존재하였는데, '가구', '옷', '부억용품' '채소', 
'소지품'을 포함한 5 개 범주에서 여자가 남자보다 평균 1개 정도 반 응수가 높게 나타났다. 기존의 국내 노인 45명을 대상으로 명사 범 주별 본보기 산출빈도를 살펴본 Sung 등(2014) 의 연구에서는 '신 체부위’를 제외한 ‘옷, '주방용품', '교통수단', ‘채소', '가구' 등의 범 주에서 성별 차이가 관찰되지 않았다. 그러나 본 연구의 대상자수 는 220 명으로 조사 단위가 확대됨에 따라 성별 차이가 관찰되는 범 주가 더 많이 나타난 것으로 해석할 수 있다. 상기 언급한 결과들을 종합해 본다면, 이름대기 중재를 위한 치료 자극 목록을 선정할 때 치료 효과를 위해서는 대상자의 해당 연령대와 성별을 고려하여 그 에 적합한 목록을 구성할 필요가 있겠다.

이름대기 중재에서 고려해야 할 또 다른 한 가지 요소로는, '전형 성' 차원이 있다. 명사의 여러 가지 속성이 이름대기 수행에 영향을 미칠 수 있는데(Kim \& Kang, 2005), 그 중에서도 '명사가 일상생활 에서 얼마나 자주 쓰이고, 얼마나 친숙한가'와 관련된 명사 친숙도 는 주관적인 속성이 반영된 빈도의 개념을 뜻한다. 친숙도가 높은 본보기들은 일반적으로 회상 순서가 빠른 편이고, 범주 유창성 과제 에서도 전형적인 본보기들을 먼저 인출하는 편이기 때문에(Rosch, 1978) 회상순서와 전형성, 친숙도는 모두상관성이 높다고 볼수 있다. 국내 60대 노인을 대상으로 명사 통제단어연상검사의 본보기 목록 에 대한 의미전형성과 친숙도 간의 관계를 살펴본 Sung 등(2014)의 연구에서도 의미전형성과 친숙도 간의 관계는 매우 높은 것으로 밝혀졌다. 본 연구에서는 1 단계에서 산출된 10 개 범주 별 상위 30 순위 안에 포함된 총 300 개 어휘 본보기에 대해서 전형성 평정만을 실시하였다. 평정 점수의 범주 간 표준화를 위해, 각 범주별 본보기 에 대한 의미전형성을 z-score로 환산하여 제시하였는데, 4 개 연령 그룹별로 나누어 의미전형성 평정 결과를 비교해 보았을 때, '소지 품, '교통수단' ‘주방용품', '학용품' 범주의 일부 본보기에서 연령 집단 간의 전형성 평정이 다소 차이가 나타나는 것을 관찰할 수 있 었다. 예를 들어, ‘먹'과 ‘벼루’ 본보기를 55-59세 집단은 학용품 범 주의 대표적 본보기로 인식하고 있지 않는 반면, 나머지 모든 연령 집단에서는 의미전형성이 높게 나타났다. 이는 각 세대가 자라면서 경험한 환경적, 문화적 배경과 관련이 있을 것으로 생각된다.

본 연구는 성인 신경언어장애 환자군의 이름대기 중재를 위한 언 어재활 프로그램 구성의 기초자료를 확보하기 위해 55-74세 정상 성인이 생성한 어휘의 성별 및 연령에 따른 차이를 확인하고 기존 의 연구에서 제시한 결과(Sung et al., 2014)에 샘플 사이즈와 연령 을 확대시켜 어휘목록을 제시하였다. 이 연구 결과를 토대로 어휘 산출 빈도와 전형성 등을 고려한 여러 가지 방식의 이름대기 중재 가 실시될 수 있으며, 이를 통해 중재 효과를 살펴보는 연구가 좀 더 다양화될 수 있을 것이다.

\section{REFERENCES}

Birn, R. M., Kenworthy, L., Case, L., Caravella, R., Jones, T. B., Bandettini, P. A., ... \& Martin, A. (2010). Neural systems supporting lexical search guided by letter and semantic category cues: a self-paced overt response fMRI study of verbal fluency. Neuroimage, 49, 1099-1107.

Christensen, K. J., Multhaup, K. S., Nordstrom, S., \& Voss, K. (1991). A cognitive battery for dementia: development and measurement characteristics. Psychological Assessment: A Journal of Consulting and Clinical Psychology, 3, 168-174.

Chung, E., Hwang, Y. M., \& Hong, J. (2014). The diversity and universality of the knowledge in semantic categories: insights from the animal category fluency task. Discourse and Cognition, 21, 209-232.

Collins, A. M., \& Loftus, E. F. (1975). A spreading-activation theory of semantic processing. Psychological Review, 82, 407-428.

Crossley, M., D’arcy, C., \& Rawson, N. S. (1997). Letter and category fluency in community-dwelling Canadian seniors: a comparison of normal participants to those with dementia of the Alzheimer or vascular type. Journal of Clinical and Experimental Neuropsychology, 19, 52-62.

Forde, E. M. (1999). Category specific recognition impairments: a review of important case studies and influential theories. Aphasiology, 13, 169-193.

Goñi, J., Arrondo, G., Sepulcre, J., Martincorena, I., de Mendizábal, N. V., Corominas-Murtra, B., ... \& Villoslada, P. (2011). The semantic organization of the animal category: evidence from semantic verbal fluency and network theory. Cognitive Processing, 12, 183-196.

Hampton, J. A., \& Gardiner, M. M. (1983). Measures of internal category structure: a correlational analysis of normative data. British Journal of Psychology, 74, 491-516.

Hasselhorn, M. (1992). Task dependency and the role of category typicality and metamemory in the development of an organizational strategy. Child Development, 63, 202-214.

Henry, J. D., \& Crawford, J. R. (2004). Verbal fluency deficits in Parkinson's disease: a meta-analysis. Journal of the International Neuropsychological Society, 10, 608-622.

Im, J. H., Lee, K. S., Kim, K. Y., Hong, N. S., Lee, S. W., \& Bae, H. J. (2011). Follow-up study on mortality in Korean stroke patients. Journal of the Korean Medical Association, 54, 1199-1208.

Jeun, D. I., \& Kang, Y. (2007). Category norms of Korean for elementary school children. Korean Journal of Communication Disorders, 12, 90-104.

Kang, Y. (2006). A normative study of the Korean-Mini Mental State Exami- 
nation (K-MMSE) in the elderly. Korean Journal of Psychology: General, $25,1-12$.

Kim, J. S., \& Kang, S. K. (2005). The effect of superordinate categorization training on naming ability of Alzheimer's disease patients. Communication Disorder, 28, 93-114.

Kim, J., \& Kim, H. (2012). Animal naming performance in Korean elderly: effects of age, education, and gender, and typicality. International Journal of Contents, 8, 26-33.

Kim, T. H. (2010). Generative naming task on place vocabulary in normal adults (Master's thesis). Yonsei University, Seoul, Korea.

Kiran, S. (2008). Typicality of inanimate category exemplars in aphasia treatment: further evidence for semantic complexity. Journal of Speech, Language, and Hearing Research, 51, 1550-1568.

Kiran, S., \& Thompson, C. K. (2003). The role of semantic complexity in treatment of naming deficits: training semantic categories in fluent aphasia by controlling exemplar typicality. Journal of Speech, Language, and Hearing Research, 46, 608-622.

Lucas, J. A., Ivnik, R. J., Smith, G. E., Bohac, D. L., Tangalos, E. G., Graff-Rad- ford, N. R., ... \& Petersen, R. C. (1998). Mayo's older Americans normative studies: category fluency norms. Journal of Clinical and Experimental Neuropsychology, 20, 194-200.

Rhee, K. Y. (1991). Korean category norms: survey on exemplar frequency norm, typicality, and features. Korean Journal of Experimental and Cognitive Psychology, 3, 131-160.

Rosch, E. (1973). On the internal structure of perceptual and semantic categories. In T. E. Moore (Ed.), Cognitive development and the acquisition of language (pp. 111-144). New York, NY: Academic Press.

Rosch, E. (1978). Principles of categorization. In E. Rosch \& B. B. Lloyd (Eds.), Cognition and categorization (pp. 27-48). Hillsdale, NJ: Erlbaum.

Rosch, E., \& Mervis, C. B. (1975). Family resemblances: studies in the internal structure of categories. Cognitive Psychology, 7, 573-605.

Sung, J. E., Mo, K. O., Lee, J. S., \& Sim, H. S. (2014). Production frequency, semantic typicality, and familiarity of noun exemplars for elderly adults. Communication Sciences \& Disorders, 19, 213-225.

Ventura, P., Morais, J., \& Kolinsky, R. (2005). Evaluating feature-category relations using semantic fluency tasks. Brain and Cognition, 58, 202-212. 
Appendix 1. 각 범주별 산출된 본보기와 산출 총수

[꽃]

장미(=들장미)(244), 진달래(=참꽃, 창꽃)(136), 개나리(129), 국화(117), 백합(83), 무궁화(79), 봉선화(=봉숭아꽃)(70), 코스모스(70), 튤립(69), 철쭉(67), 벗꽃 (65), 목련(62), 채송화(60), 민들레(55), 나팔꽃(54), 해바라기(45), 난꽃(=난초)(44), 수선화(41), 할미꽃(38), 매화(=설중매)(35), 안개꽃(=물안개꽃)(35), 백일홍 (35), 라일락(30), 아카시아꽃(30), 동백꽃(28), 배꽃(27), 카네이션(26), 찔레꽃(26), 맨드라미(24), 복숭아꽃(=복사꽃)(24), 제비꽃(=오랑캐꽃)(22), 수국(=수국화) (22), 들국화(19), 살구꽃(18), 호박꽃(18), 사과꽃(17), 해당화(15), 선인장꽃(=선인장)(15), 후리지아(=후리지어, 후레지아, 프리지어, 프리지아)(15), 분꽃(14), 연꽃 (11), 패랭이꽃(=패랭이, 파랭이꽃)(10), 야래향(=달맞이꽃)(9), 연산홍(=연신홍, 연상홍)(8), 박꽃(8), 군자란(7), 팬지(7), 히아신스(=히야신스)(7), 붓꽃(6), 천리향 $(=$ 천리꽃)(6), 유채꽃(=유채화)(6), 산수유(6), 채키화(=접시꽃)(6), 호접난(=호접)(6), 목단(=목단꽃)(6), 금잔화(=군잔화)(5), 밤꽃(=밤나무꽃)(5), 문주란(5), 감꽃(=감 나무꽃)(5), 양귀비(4), 글라디올로스(=글라디오스, 그라디오스, 글라디올러스)(4), 도라지꽃(4), 싸리꽃(4), 나리꽃(3), 수련(=수련화)(3), 과꽃(=가꽃, 당국화)(3), 오 이꽃(3), 벤자민(3), 물망초(3), 야생화(3), 메밀꽃(3), 제라늄(3), 목화꽃(3), 알로애(=알로에)(2), 자스민(=재스민)(2), 안동초(2), 대국(2), 소국(2), 대추꽃(=대추나무 꽃)(2), 금낭화(2), 엉겅퀴(2), 들꽃(2), 함박꽃(2), 산세베리아(2), 작약(=자약)(2), 사루비아(2), 달래꽃(2), 감자꽃(2), 병꽃(1), 섬초롱꽃(=선초롱)(1), 복수초(1), 구절 초(1), 공작(1), 백리향(1), 키다리꽃(1), 금송화(1), 달팽이꽃(1), 양난(1), 동양난(1), 참외꽃(1), 마타리(1), 배초향(1), 꽃향유(1), 으아리(1), 달개비꽃(1), 산초(1), 은 방울꽃(1), 홍등화(=홍동화꽃)(1), 원추리(1), 깨꽃(1), 아네모네(1), 아이비(1), 장수매(1), 백화등(1), 깅기아난(1), 인삼꽃(1), 벼꽃(1), 콩꽃(1), 팥꽃(1), 냉이꽃(1), 바 이올렛(1), 달리아(1), 산수화(1), 사랑꽃(1), 매실꽃(1), 인동꽃(1), 매꽃(1), 천일홍(1), 초란(1), 산채꽃(1), 창포(1), 상사화(1), 무화과꽃(1), 옥잠(1), 백련꽃(1), 귤꽃 (1), 라벤더(1), 페추니아(1), 백년초(1), 고구마꽃(1), 활련화(1), 불두화(1), 보이꽃(1), 풍란(1), 양생화(1), 투구꽃(1), 칡꽃(1), 앵두(1)

\section{[옷]}

잠바 $=$ 점퍼, 점바, 돕바, 겨울돕바, 겨울잠바, 여름잠바, 봄잠바)(135), 티셔츠(=티, 티샤츠)(124), 바지 $(=$ 팬츠)(122), 팬티 $=$ 빤스)(115), 양말(107), 코트 $(=$ 오바코트, 오버코트)(105), 양복(=정장, 신사복, 신사정장, 슈트, 수트, 양폭, 양복상하)(96), 런닝(=런닝복, 런닝셔츠, 런닝구, 난닝구, 난닝셔츠, 넌닝구, 반팔런닝, 메리야스(=메 리아스, 메리야쓰)(94), 내의(=내복, 겨울내복, 솜내의, 냐의, 내의잠옷)(91), 셔츠(=와이셔츠)(78), 치마(=스커트)(78), 조끼(62), 한복(=저고리, 치마저고리)(54), 스 웨터(=스웨타, 세타, 털세터, 쉐타)(46), 블라우스(=브라우스)(42), 반바지(42), 목도리(=머플러, 목플러, 마후라, 마우라)(41), 속옷(40), 원피스(=원페수)(38), 남방 $=$ 난방)(37), 추리닝(=추리링, 츄리닝, 츄리링)(36), 브라(=브라자, 브래지어, 브레이지어, 브레지어)(35), 장갑(34), 등산복(=등산옷, 등산본)(33), 가디건(30), 모자(26), 트렌치코트(=바바리, 바바리코트, 버버리)(25), 스타킹(25), 투피스(24), 재킷(=자켓, 쟈켓, 솜자켓, 마이자켓)(22), 청바지(22), 잠옷(=파자마)(22), 넥타이(=타이) (22), 양복상의 $(=$ 가다마이, 가다마, 가드마이, 마이) $(21)$, 운동복 $=$ 스포츠옷, 트레이닝복, 체육복 $(20)$, 파카 $(=$ 오리털파카 $)(13)$, 목티 $(=$ 폴라티)(12), 패딩잠바(=패딩, 패팅)(12), 속치마(11), 외투(=겉옷, 겉옥, 오버, 오바)(10), 쫄바지(=레깅스)(9), 드레스(9), 버선(9), 양장(8), 긴바지(8), 정장바지(=기지바지, 양복하의, 신사복바지, 쓰범)(8), 속바지(8), 우의(=우비, 비옷, 레인코트)(8), 스카프(8), 쓰리피스(7), 수영복(=비키니)(7), 반팔티(=반소매티셔츠)(6), 롱코트(6), 밍크코트(=밍크옷)(6), 면티 (5), 면바지(5), 짧은치마(=미니스커트)(5), 반코트(4), 긴치마(=롱스커트, 월남치마)(4), 근무복(=작업복)(4), 방한복(4), 드루마기(=두루마)(4), 상의(=윗옷, 윗도리) (3), 나시(3), 후드티(3), 가죽잠바(3), 오리털점퍼(=오리털잠바)(3), 사파리잠바(=사파리)(3), 거들(3), 유니폼(=제복)(3), 골프복(=골프옷, 골프웨어)(3), 덧버선(=덮버 선, 덧신(3), 쫄티(2), 브이티(2), 라운드티(2), 카라티(2), 오리코트(=오리털코트, 털코트)(2), 나팔바지(2), 몸빼바지(2), 삼각팬티(2), 사각팬티(2), 웨딩드레스(2), 스 키복(2), 목폴라(2), 고쟁이(2), 긴팔티(1), 청잠바(1), 털잠바(1), 하의(1), 골덴바지(1), 맘모바지(1), 누빔바지(1), 패딩바지(1), 주름치마(1), 청치마(1), 타이즈(1), 군 복(1), 턱시도(1), 가운(1), 등산양말(1), 등산용내피(1), 등산용바지(1), 축구복(1), 야구복(1), 땀복(1), 여우목도리(1), 족제비목도리(1), 혁띠(1), 속저고리(1), 마고자 (1), 아오자이(1)

\section{[가구]}

장롱 $=$ 장, 단스, 농, 장롱)(171), 의자 $=$ 걸상, 안락의자, 흔들의자, 안마의자)(169), 책상(168), 식탁(131), 침대(127), 서랍장(=삼단서랍장, TV서랍장, 옷서랍장, 5단 서랍장, 서랍, 고다스, 고단스)(114), 소파 $=$ 쇼파, 가죽소파)(100), 화장대(=경대)(99), 책장 $(=$ 책꽃이)(83), 옷장(76), 문갑 $(=$ 문갑장, 문각)(72), 장식장 $(=\mathrm{TV}$ 장식장, 컴 퓨터장식장, 진열장, 커피진열장, 술진열대장, 차단스, 선반장, 그릇장)(56), 탁자(=좌탁, 탁상)(43), 신발장(=신장, 신발자)(40), 싱크대(33), 찬장(31), TV다이(=테레 비다이, TV받침대, 텔레비전받침대, 텔레비전밑받침, 티비받침, TV진열대)(30), 이불장(13), 상(=테이블, 쇼파용테이블, 소파랑 같이 놓는 테이블)(13), 옷걸이(=헹거) (11), 선반 $(=$ 판, 선반대)(10), 협탁(10), 벽장 $(=$ 붙박이장, 붙박이)(9), 컴퓨터책상 $(=$ 컴퓨터테이블 $)(9)$, 거울 $(=$ 전신거울 $)(8)$, 거실장 $(7)$, 반닫이 $(=$ 앞다지)(6), 진열대(6), 밥상(5), 장식대(4), TV선반(3), 렌지대(=렌지다이)(3), 차상(=티테이블)(3), 컴퓨터다이(2), 수납장(2), 자개장(2), 캐비닛(2), 컴퓨터 선반(1), 밥솥선반(1), 거실다이 (1), 화분대(1), 교자상(1), 평상(1), 벤치(1), 머릿장(1), 뒤주(1), 콘솔(1), 킹침대(1), 더블침대(1), 싱글침대(1), 미닫이장(1), 텐트장(1), 양말장(1), 양복장(1), 옷걸이 장(1), 빨래걸이(1)

\section{[교통수단]}

택시(174), 버스(172), 비행기(168), 자전거(=두발자전거)(164), 기차(=열차)(154), 지하철(=전철)(145), 오토바이(140), 배(=선박)(88), 승용차(77), 트럭(67), 차(= 자동차)(42), 화물차(28), $\mathrm{KTX}(=$ 고속기차, ITX)(26), 승합차 $(=$ 봉고차)(24), 경운기(22), 헬리콥터(=헬기)(17), 고속버스(16), 여객선(13), 시내버스(11), 리어카(10), 관광버스(9), 유람선(8), 스쿠터(8), 전차(7), 잠수함(6), 마을버스(6), 용달차(6), 마차(6), 보트(5), 덤프트럭(5), 레저용차(=캠핑카, RV)(5), 이삿짐차(=짐차)(5), 요트 (4), 시외버스(4), 짚차(4), 소방차(4), 포크레인(4), 인력거(4), 통근버스(=통학버스)(3), 9인승버스(=미니버스, 셔틀버스)(3), 트렉터(3), 항공기(2), 제트기(2), 어선 (2), 유조선(2), 증기선(2), 쾌속선(=쾌속정)(2), 대형버스(=16인승버스)(2), 수상택시(2), 유통차(=택배차)(2), 소형차(2), 경차(2), SUV(2), 구조차(=엠뷸런스)(2), 케 이블카(2), 탱크(2), 가마(2), 달구지(=소달구지)(2), 수레(2), 딸딸이(2), 모노레일(1), 여객기(1), 전투기(1), 수송기(1), 경비행기(1), 상선(1), 덩크선(1), 벌크선(1), 견 인선(1), 모터보트(1), 유자망선(1), 항공모함(1), 통통배(1), 화물선(1), 카누(1), 돛단배(1), 나룻배(1), 군함(1), 광역버스(1), 전동자전거(1), 세발자전거(1), 레미콘(1), 기름차(1), 특장차(1), 장의차(1), 순찰차(1), 스포츠카(1), 우주선(1), 사륜차(1), 굴삭기(1), 지게차(1), 휠체어(1)

\section{[소지품]}

지갑(=손지갑)(179), 휴대폰(=폰, 스마트폰, 핸드폰, 전화, 전화기, 휴대전화)(179), 손수건(112), 볼펜(=펜)(75), 가방(74), 돈(=현금, 현찰)(73), 신용카드(=카드, 비 씨카드, 은행카드, 현금카드, 체크카드)(72), 열쇠(=키)(66), 안경(65), 휴지(=화장지, 티슈, 일회용휴지)(44), 수첩(=거래수첩)(43), 화장품(=화장품샘플, 화장품통) (42), 자동차키 $(=$ 차키)(41), 시계 $(=$ 애플워치, 손목시계)(40), 담배(35), 거울 $(=$ 손거울)(32), 라이타 $(=$ 라이터)(31), 루즈 $(=$ 립스틱)(26), 양산(25), 모자(25), 물티슈 (21), 교통카드(=버스카드, 버스표)(20), 반지(=결혼반지)(19), 통장(19), 핸드백(=손가방)(18), 주민등록증(=민증, 주민등록)(18), 물(=물병, 물통, 휴대용물병)(18), 돋보기 안경 $=$ 돋보기 $)(16)$, 약 $(=$ 상비약, 먹는약, 약통, 비상약, 비상약품)(15), 빗 $(=$ 머리빗 $)(14)$, 목걸이(13), 운전면허 $(=$ 운전면허증, 면허증 $)(13)$, 집열쇠 $(=$ 집키)(12), 연필(11), 메모지(=메모용지, 적어가지고 다니는 종이, 메모장)(11), 장갑(=면장갑)(11), 우산(11), 책(11), 선글라스(10), 신분증(10), 성경책(=기도책)(10), 안경수건 $(=$ 안경닦이)(9), 도장(8), 명함(=명함들)(8), 팔찌 $(=$ 금팔찌)(7), 칫솔 $=$ 일회용칫솔 $)(7)$, 동전(6), 이쑤시개(6), 부채(6), 이어폰(6), 자외선차단제 $(=$ 선크림)(5), 로션(5), 시장바구니 $(=$ 장바구니 $)(5)$, 지하철카드 $(=$ 지하철표, 지하철패스, 승차권 $)(5)$, 명함집 $=$ 명함지갑 $)(4)$, 키홀더 $(=$ 열쇠고리 $)(4)$, 가그린 $(=$ 가글 $)(4)$, 손톱깎기 $(=$ 손톱깎이) (4), 지팡이 (=지팽이)(4), 팩트(=콤팩트, 딱분)(3), 핸드크림(3), 핸드폰배터리(=배터리)(3), 만년필(3), 다이어리(3), 공책(=노트)(3), 스카프(3), 마스크(3), 바늘(3), 동 전지갑(2), 비비크림(2), 립글로즈(2), 향수(2), 화장품백(=화장품가방)(2), 카드키(2), 아파트현관키(2), 자전거키(2), 회사키(=사무실키)(2), 비타민(=비타민통, 비타 민약)(2), 필기도구(=필기구)(2), 필통(2), 안경집(2), 귀걸이(2), 핀(=삔)(2), 손청결제(=손소독약)(2), 수건(2), 치약(2), 사진(2), 컵(=휴대용컵)(2), 실(2), 염주(2), 전 
55-74세 성인의 명사 범주 규준 조사 • 김정완 외

화번호부(=연락처수첩)(2), 카드지갑(1), 패스포트지갑(1), 카드키홀더(1), 파운데이션(1), 헤어에센스(1), 돈가방(1), 책가방(1), 바구니(1), 가게키(1), 오토바이키(1), 보안카드(1), 파일(1), 미니수첩(1), 지우개(1), 머리끈(=고무줄)(1), 머리띠(1), 머리핀(1), 수표(1), 상품권(1), 비상금(1), 용돈(1), 선캡(=썬캡)(1), 면도기(1), 손톱가 위(1), 성냥(1), 우비(1), 충전기(1), 쿨토시(1), 서류(1), 계산기(1), 묵주(1), 배지(1), 반창고(1,) 호신용호루라기(1), usb(1), 영어사전(1), 노트북(1), 카메라(1), 신주걱 (1), 옷핀(1), 액세서리(1)

\section{[동물]}

소(177), 호랑이(=범)(171), 돼지(161), 개(158), 닭(147), 사자(146), 말(145), 고양이(131), 토끼(121), 염소(101), 원숭이(99), 양(93), 코끼리(88), 기린(71), 쥐 (70), 사슴(62), 오리(61), 늑대(58), 여우(57), 뱀(52), 강아지(45), 곰(43), 노루(39), 하마(34). 표범(32), 악어(31), 낙타(30), 다람쥐(28), 독수리(27), 얼룩말(25), 너구리(24), 치타(23), 참새(21), 고래(20), 멧돼지(20), 물개(20), 꿩(19), 비둘기(18), 캥거루(18), 코뿔소(18), 고라니(17), 새(17), 오소리(16), 까치(14), 하이에나 (13), 거위(12), 까마귀(12), 살쾡이(12), 코알라(12), 타조(12), 물소(10), 펭귄(10), 기러기(9), 두더지(9), 산양(8), 상어(8), 송아지(8), 개구리(7), 병아리(7), 고슴도 치(6), 공작(=새)(6), 들소(6), 앵무새(6), 거북이(5), 고릴라(5), 수달(5), 청솔모(5), 매(4), 박쥐(4), 부엉이(4), 영양(4), 오랑우탄(4), 이구아나(4), 조랑말(4), 칠면조 (4), 햄스터(4), 구렁이(3), 꾀꼬리(3), 당나귀(3), 망아지(3), 물고기(3), 산돼지(3), 솔개(3), 올빼미(3), 재규어(3), 제비(3), 고니(2), 나무늘보(2), 담비(2), 도마뱀(2), 독사(2), 들개(2), 메뚜기(2), 미어캣(2), 북극곰(2), 산토끼(2), 시라소니(2), 이리(2), 족제비(2), 침팬지(2), 파랑새(2), 팬더(2), 학(2), 홍학(2), 황새(2), 개코원숭이(1), 경주말(1), 구관조(1), 금붕어(1), 꽁치(1), 농어(1), 대머리독수리(1), 도룡뇽(1), 마르티지(1), 메추리(1), 멸치(1), 명태(1), 문어(1), 물뱀(1), 물총새(1), 바다표범(1), 반달곰(1), 발바리(1), 방울뱀(1), 백곰(1), 백조(1), 뱁새(1), 벼룩(1), 붕어(1), 사람(1), 사향노루(1), 살모사(1), 십자매(1), 암탉(1), 오골계(1), 임팔라(1), 잉어(1), 자 칼(1), 장어(1), 전갈(1), 진돗개(1), 찌르레기(1), 철갑상어(1), 철새(1), 청둥오리(1), 치와와(1), 카나리아(1), 파리(1), 포메라니안(1), 푸들(1), 퓨마(1), 흑염소(1)

\section{[주방용품]}

냄비(153), 칼(=식칼, 부억칼)(148), 도마(=칼도마)(127), 국자(118), 프라이팬(=후라이팬)(114), 젓가락(=저분, 젓갈)(113), 접시 $(=$ 앞접시)(102), 밥그릇 $(=$ 공기, 밥 공기, 밥사발)(100), 숟가락 $(=$ 숟갈, 스푼)(100), 주걱(72), 밥솥 $==$ 밥통)(63), 가위 $(=$ 부억가위) $(55)$, 가스레인지 $(=$ 가스렌지) $(50)$, 전자레인지 $(=$ 렌지) $(50)$, 국그릇 $(=$ 국 대접)(48), 컵(46), 그릇 $(=$ 그릇세트)(45), 수저(45), 주전자(45), 냉장고(38), 포크(38), 솥 $(=$ 솥단지)(33), 전기밥솥 $(=$ 전기솥, 전기밥통, 전자밥솥)(32), 집게(31), 뒤집 개 $(=$ 뒤집기, 전뒤집기)(30), 쟁반 $(=$ 오봉)(30), 압력솥 $(=$ 압력밥솥) $(26)$, 대접 $(24)$, 수세미(22), 믹서기 $(=$ 믹서)(20), 종지 $(=$ 종지그릇, 종발, 종발이, 종재기)(19), 커피포 트(19), 행주(19), 찜기(=찜솥, 찜통)(16), 양푼 $(=$ 양푼이, 양재기)(14), 커피잔(14), 뚝배기(13), 김치냉장고(12), 바가지(12), 사발(10), 티스푼 $=$ 차숟가락)(10), 오븐 $(=$ 오븐기)(9), 찻잔(9), 감자칼 $(=$ 감자깎이, 고구마칼 $)(7)$, 고무장갑(7), 물잔 $(=$ 물컵)(7), 바구니(7), 반찬통 $(=$ 찬통 $)(7)$, 유리컵 $(=$ 유리잔, 글라스 $)(7)$, 주방세제 $(=$ 세제 $)(7)$, 다라(=다라이, 양은다라)(6), 물병(6), 양념통(6), 조리(6), 냄비받침대(=냄비받침, 받침대)(5), 반찬그릇(=찬그릇)(5), 소쿠리(5), 수저통(5), 정수기(5), 채반(=뜰채) (5), 과도 $(=$ 과도칼, 과일칼)(4), 나무젓가락(4), 냉면그릇(=냉면대접)(4), 도시락(=도시락통)(4), 상(4), 양은냄비(4), 일회용비닐(=비닐팩)(4), 전골냄비(4), 곰솥(3), 다 짐기 $(=$ 마늘다지기, 마늘다짐기)(3), 물통(3), 병따개(3), 술잔(3), 식기세척기(=세척기)(3), 칼갈이돌 $(=$ 칼갈이)(3), 호일(3), 간장종지(2), 강판(2), 거품기(2), 김치통 (2), 나이프(2), 녹즙기(2), 사기그릇(2), 석쇠(2), 양동이(2), 양은솥(=양은밥솥)(2), 절구(2), 중탕기(=중탕솥)(2), 토스트기(2), 튀김기(2), 함지박(2), 항아리(2), 가마 솥(1), 커피포트(1), 거름망(1), 계량스푼(1), 과일접시(1), 교자상(1), 국솥(1), 궁중팬(1), 김밥말이(1), 깔때기(1), 냉동고(1), 돌솥(1), 들통(1), 막걸리잔(1), 머그잔(1), 무채접시(1), 믹싱볼(1), 밀대(1), 밀폐용기(1), 반상기(1), 밥주걱(1), 보온통(1), 볼(1), 분쇄기(1), 빙설기(1), 설거지통(1), 소주잔(1), 식기(1), 식기건조기(1), 약탕기 (1), 양념종기(1), 옹기(1), 와인잔(1), 인덕션레인지(1), 일회용장갑(1), 잔(1), 저울(1), 전기오븐(1), 전기후라이팬(1), 젓가락통(1), 조미료통(1), 찻상(1), 채칼(1), 커 피머신(1), 키친페이퍼(1), 튀김팬(1), 티받침(1), 플라스틱그릇(1)

\section{[학용품]}

연필(215), 지우개(167), 볼펜(165), 공책(=노트)(119), 크레파스(=크레용)(90), 필통(89), 만년필(77), 색연필(72), 자(71), 칼(=커터칼)(68), 사인펜(59), 가위(49), 도화지(46), 색종이 $(=$ 색지)(46), 물감(=수채화물감, 그림물감)(46), 스케치북(40), 샤프(=샤프펜슬)(39), 풀(=딱풀)(35), 붓(35), 컴퍼스(33), 책받침(=공책받침)(33), 연필깎이(24), 매직(20), 삼각자(20), 종이(18), 연습장(15), 벼루(15), 형광펜(13), 먹(=묵)(12), 잉크(11), 각도기(11), 수첩(10), 테이프(=스카치테이프)(9), 수성펜 (=수성사인펜)(8), 샤프심(=연필심)(8), 수정펜(=화이트)(7), 줄자(7), 호치케스(7), 팔레트(5), 펜(4), 습자지(4), 파일(4), 클립(4), 네임펜(3), 붓펜(3), 일기장(3), 캔트 지(3), A4용지(3), 마분지(3), 먹물(3), 연필꽃이(3), 다이어리(3), 유성펜(2), 원고지(2), 종합장(2), 받아쓰기공책(=받아쓰기장)(2), 화선지(2), 한지(2), 연필깎는 칼 (2), 제도기 $(=$ 작도기)(2), 분도기(2), 본드(2), 압정(2), 견출지(2), 집게(2), 다색볼펜(1), 모눈종이(1), 골판지(1), 사절지(1), 하드보드지(1), 포스트잇(1), 양면지(1), 모 조지(1), 전지(1), 기름종이(1), 먹지(1), 오선지(1), 학종이(1), 메모지(1), 수정테이프(1), 포스터칼라(1), 파스텔(1), 물감통(1), 각자(1), 육각자(1), 긴자(1), 파일정리 함(1), 스티커(1), 돋보기(1), 화이트보드(1), 자석(1), 주판(1), 컬러펜(=색깔펜)(1)

\section{[채소]}

배추(195), 무(151), 시금치(135), 상추(131), 대파(=조선파, 파)(127), 당근(117), 양파(116), 오이(85), 고추(79), 양배추(78), 감자(71), 쑥갓(70), 미나리(70), 마늘 (=통마늘)(66), 부추(=정구지)(58), 고구마(55), 브로콜리(54), 토마토(51), 호박(50), 콩나물(45), 깻잎(35), 도라지(34), 가지(31), 피망(31), 고사리(28), 우엉(28), 열무(27), 양상추(25), 파프리카(25), 쪽파(24), 냉이(22), 치커리(21), 생강(21), 숙주나물(20), 연근(19), 버섯(17), 취나물(17), 아욱(13), 달래(12), 유채(=겨울초, 동초, 월동초)(11), 근대(11), 콜라비(9), 더덕(9), 파슬리(8), 갓(=갓나물)(8), 느타리버섯(6), 청경채(6), 비트(=빨간무)(6), 시래기(6), 풋고추(5), 순무(5), 봄동(5), 씀 바귀(5), 쑥(5), 토란(5), 셀러리(4), 고구마줄기(=고구마대)(4), 송이버섯(3), 고수(3), 콩잎(3), 알타리무(=달랑무)(3), 참나물(3), 돌나물(3), 토란대(3), 표고버섯(2), 팽이버섯(2), 꽈리고추(2), 청양고추(=땡초)(2), 옥수수(2), 마늘종(2), 들깻잎(2), 총각무(2), 마(2), 돼지감자(2), 고들빼기(2), 새송이버섯(1), 목이버섯(1), 상황버섯 (1), 오이고추(1), 방울토마토(1), 애호박(1), 수세미(1), 풋마늘(1), 섬초(1), 새싹(1), 무순(1), 들미나리(1), 깨순(=깻순)(1), 얼갈이배추(1), 두릅(1), 질경이(1), 비름 (1), 알로에(1), 곤드레(1), 갓나물(1), 봄나물(1)

\section{[전자제품]}

$\mathrm{TV}(186)$, 전자레인지(134), 냉장고(112), 세탁기(=삶는 세탁기)(106), 컴퓨터(=PC)(101), 전기밥솥(=밥솥, 압력밥솥, 전기압력밥솥, 밥통)(94), 에어컨(=벽걸이에어 컨)(86), 김치냉장고(82), 휴대폰(=핸드폰, 스마트폰, 휴대전화)(73), (앉은뱅이, 거실용, 탁상용)선풍기(67), 라디오(65), (진공)청소기(59), 전기주전자(=전기포트, 커 피포트)(58), 다리미(57), 드라이기(53), (집)전화기(=유선전화기)(46), 믹서기(36), 오디오(=전축)(34), 전기오븐(=오븐, 오븐레인지)(34), 비디오(=VTR)(31), 정수기 (=냉온수기)(22), 가습기(22), 온풍기(21), 전기난로 $(=$ 히터, 전기스토브, 전열기, 온열제품 $)(21)$, 전기면도기 $(=$ 면도기)(19), 전기장판 $(=$ 전기매트)(19), 카메라 $(=$ 사진 기)(16), 식기세척기(=세척기)(14), 전기후라이팬(13), 전자시계(=시계)(13), 냉동고(13), 녹음기(13), 공기청정기(11), 노트북(11), 안마기(=전기마사지)(11), (핸드 폰, 차량용)충전기(11), 고데기(9), 식품건조기(=건조기)(9), 토스트기(9), 카세트(8), 스탠드(8), 제습기(7), 복사기(7), 프린터기(=인쇄기)(7), 형광등(=전등, 전열등) (6), 리모컨(6), 커피메이드(=커피머신)(5), 전기소독기(4), 진동칫솔(=전동칫솔)(4), 런닝머신(4), 전기그릴(4), 인덕션(=전기레인지)(4), 팩스(4), 안마의자(4), 온장고 (3), 와인냉장고(3), MP3(3), 비디오카메라(=캠코더)(3), 녹즙기(3), 냉난방기(=난방기, 냉방기)(3), 계산기(3), 후레쉬(=전기랜턴)(3), 내비게이션(2), 스팀다리미(2), 환풍기(2), 스팀청소기(=스팀기)(2), 전동자전거(2), 식기건조기(2), 카터기(2), 분쇄기(2), 튀김기(2), 전기담요(=전기요)(2), 온수매트(2), 전자수첩(2), 키보드(2), 마 우스(2), 컴퓨터모니터(2), 스피커(2), 태블릿PC(2), 전자피아노(=전자오르간)(2), 화장품냉장고(1), 곡식냉장고(1), DVD(1), 블랙박스(1), CCTV(1), 로봇청소기(1), 비데(1), 코털깎이(1), 전기후드(1), 젓병소독기(1), 전기냄비(1), 고추건조기(1), 에어포트(1), 프로젝터(1), 족욕기(1), 게임기(1), 제초기(1), 전자담배(1), 무전기(1) 
Appendix 2. 각 범주별 1 위에서 30 위에 해당하는 본보기의 z-score

[꽃]

장미(=들장미) (-0.55), 진달래(=참꽃, 창꽃)(-0.43), 개나리(-0.46), 국화(-0.48), 백합(-0.29), 무궁화 $(-0.39)$, 봉선화 $(=$ 봉숭아꽃 $)(0.04)$, 코스모스(-0.34), 튤립 $(-0.06)$, 철쭉 $(-0.12)$, 벚꽃 $(-0.29)$, 목련 $(-0.15)$, 채송화 $(0.09)$, 민들레 $(0.06)$, 나팔꽃 $(0.02)$, 해바라기 $(-0.05)$, 난꽃 $(=$ 난초 $)(0.28)$, 수선화 $(0.37)$, 할미꽃 $(0.29)$, 매화 $(=$ 설중매) $(0.22)$, 안개꽃 $(=$ 물안개꽃 $)(0.27)$, 백일홍(0.28), 라일락(0.39), 아카시아꽃(0.09), 동백꽃(-0.13), 배꽃 $(0.57)$, 카네이션 $(-0.04)$, 찔레꽃(0.14), 맨드라미 (0.48), 복숭아꽃(=복사꽃 $)(0.20)$

\section{[옷]}

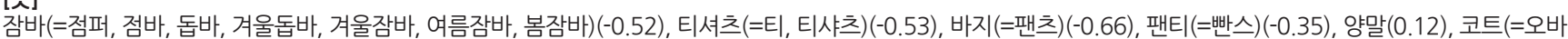
코트, 오버코트)(-0.27), 양복(=정장, 신사복, 신사정장, 슈트, 수트, 양폭, 양복상하)(-0.36), 런닝(=런닝복, 런닝셔츠, 런닝구, 난닝구, 난닝셔츠, 넌닝구, 반팔런닝, 메리 야스 $(=$ 메리아스, 메리야쓰 $)(-0.15)$, 내의 $(=$ 내복, 겨울내복, 솜내의, 냐의, 내의잠옷 $)(-0.06)$, 셔츠 $(=$ 와이셔츠 $)(-0.33)$, 치마 $(=$ 스커트 $)(-0.18)$, 조끼 $(-0.08)$, 한복 $(=$ 저고 리, 치마저고리)(0.14), 스웨터(=스웨타, 세타, 털세터, 쉐타)(0.01), 블라우스(=브라우스)(-0.04), 반바지(-0.21), 목도리(=머플러, 목플러, 마후라, 마우라)(0.57), 속 옷 $(-0.16)$, 원피스(=원페수)(-0.11), 남방(=난방)(-0.23), 추리닝 (=추리링, 츄리닝, 츄리링)(0.07), 브라(=브라자, 브래지어, 브레이지어, 브레지어)(0.36), 장갑(0.60), 등산복 $(=$ 등산옷, 등산본 $)(0.06)$, 가디건(0.13), 모자 $(0.54)$, 트렌치코트 $(=$ 바바리, 바바리코트, 버버리 $)(0.21)$, 스타킹 $(0.68)$, 투피스 $(0.24)$, 재킷 $(=$ 자켓, 쟈켓, 솜자켓, 마이자켓)(0.00), 청바지 $(-0.16)$, 잠옷 $(=$ 파자마 $)(0.12)$, 넥타이 $(=$ 타이 $)(0.58)$

\section{[가구]}

장롱 $(=$ 장, 단스, 농, 장롱 $)(-0.53)$, 의자 $=$ 걸상, 안락의자, 흔들의자, 안마의자 $)(-0.25)$ 책상 $(-0.26)$, 식탁(-0.44), 침대 $(-0.41)$, 서랍장 $(=$ 삼단서랍장, TV서랍장, 옷서랍 장, 5 단서랍장, 서랍, 고다스, 고단스 $)(-0.19)$, 소파 $(=$ 쇼파, 가죽소파 $)(-0.35)$, 화장대 $(=$ 경대 $)(-0.13)$, 책장 $(=$ 책꽃이 $)(-0.05)$, 옷장 $(-0.41)$, 문갑 $(=$ 문갑장, 문각 $)(-0.11)$, 장식장 $=T V$ 장식장, 컴퓨터장식장, 진열장, 커피진열장, 술진열대장, 차단스, 선반장, 그릇장 $(0.13)$, 탁자 $(=$ 좌탁, 탁상 $)(0.01)$, 신발장 $(=$ 신장, 신발자 $)(-0.09)$, 싱크대 (0.08), 찬장(0.10), TV다이(=테레비다이, TV받침대, 텔레비전받침대, 텔레비전밑받침, 티비받침, TV진열대)(-0.13), 이불장(-0.34), 상(=테이블, 쇼파용테이블, 소파 랑 같이 놓는 테이블 $)(-0.12)$, 옷걸이 $(=$ 헹거 $)(0.37)$, 선반 $(=$ 판, 선반대 $)(0.46)$, 협탁 $(0.73)$, 벽장 $(=$ 붙박이장, 붙박이 $)(0.22)$, 컴퓨터책상 $(=$ 컴퓨터테이블 $)(0.16)$, 거울 $(=$ 전신거울)(0.15), 거실장(0.16), 반닫이 $(=$ 앞다지)(0.44), 진열대(0.36), 밥상 $(0.11)$, 장식대 $(0.35)$

\section{[교통수단]}

택시(-0.72), 버스(-0.74), 비행기(-0.54), 자전거(=두발자전거) $(-0.19)$, 기차 $(=$ 열차 $)(-0.62)$, 지하철 $(=$ 전철 $)(-0.73)$, 오토바이 $(-0.08)$, 배 $(=$ 선박 $)(-0.24)$, 승용차 $(-0.74)$, 트럭 $(0.13)$, 차 (=자동차 $)(-0.69)$, 화물차 $(0.27), \mathrm{KTX}(=$ 고속기차, ITX) $(-0.55)$, 승합차 $(=$ 봉고차 $)(-0.40)$, 경운기 $(0.62)$, 헬리콥터 $(=$ 헬기 $)(0.61)$, 고속버스 $(-0.58)$, 여객선(-0.15), 시내버스(-0.73), 리어카(0.94), 관광버스(-0.17), 유람선(0.29), 스쿠터(0.42), 전차(0.33), 잠수함(0.97), 마을버스(-0.40), 용달차(0.45), 마 차(0.80), 보트(0.68), 덤프트럭(0.65), 레저용차 $=$ 캠핑카, RV)(0.68), 이삿짐차(=짐차)(0.42)

\section{[소지품]}

지갑(=손지갑)(-0.38), 휴대폰(=폰, 스마트폰, 핸드폰, 전화, 전화기, 휴대전화)(-0.43), 손수건(0.20), 볼펜(=펜)(0.45), 가방(0.02), 돈(=현금, 현찰)(-0.23), 신용카드 (=카드, 비씨카드, 은행카드, 현금카드, 체크카드) $(-0.27)$, 열쇠 $(=$ 키 $)(-0.24)$, 안경 $(-0.14)$, 휴지 $(=$ 화장지, 티슈, 일회용휴지 $)(0.10)$, 수첩 $(=$ 거래수첩 $)(0.34)$, 화장품 $(=$ 화 장품샘플, 화장품통 $)(-0.11)$, 자동차키 $(=$ 차키 $)(-0.27)$, 시계 $(=$ 애플워치, 손목시계 $)(0.09)$, 담배 $(0.77)$, 거울 $(=$ 손거울 $)(0.46)$, 라이타 $(=$ 라이터 $)(0.77)$, 루즈 $(=$ 립스틱 $)$ $(-0.01)$, 양산 $(0.30)$, 모자 $(0.62)$, 물티슈 $(0.28)$, 교통카드 $(=$ 버스카드, 버스표 $)(-0.11)$, 반지 $(=$ 결혼반지 $)(0.94)$, 통장 $(0.71)$, 핸드백 $(=$ 손가방 $)(-0.05)$, 주민등록증 $(=$ 민 증, 주민등록)(-0.24), 물(=물병, 물통, 휴대용물병)(0.76), 돋보기 안경 $(=$ 돋보기)(0.25), 약(=상비약, 먹는약, 약통, 비상약, 비상약품)(0.24), 빗 $(=$ 머리빗)(0.81)

\section{[동물]}

소(-0.54), 호랑이(=범)(-0.19), 돼지(-0.39), 개(-0.44), 닭(-0.24), 사자(-0.22), 말(-0.22), 고양이(-0.13), 토끼(-0.22), 염소(-0.18), 원숭이(-0.05), 양(-0.26), 코끼리 $(-0.03)$, 기린 $(0.10)$, 쥐 $(0.48)$, 사슴 $(-0.16)$, 오리 $(-0.04)$, 늑대 $(0.19)$, 여우(0.13), 뱀 $(0.63)$, 강아지 $(-0.39)$, 곰 $(-0.02)$, 노루 $(0.15)$, 하마 $(0.26)$, 표범 $(0.12)$, 악어 (0.54), 낙타(0.40), 다람쥐 $(0.13)$, 독수리(0.42), 얼룩말 $(0.16)$

\section{[주방용품]}

냄비(-0.31), 칼(=식칼, 부억칼 $)(-0.27)$, 도마 $(=$ 칼도마 $)(-0.29)$, 국자 $(-0.28)$, 프라이팬 $(=$ 후라이팬 $)(-0.23)$, 젓가락 $(=$ 저분, 젓갈 $)(-0.22)$, 접시 $(=$ 앞접시 $)(0.03)$, 밥그릇 $(=$ 공기, 밥공기, 밥사발 $)(-0.28)$, 숟가락 $(=$ 숟갈, 스푼 $)(-0.30)$, 주걱 $(-0.18)$, 밥솥 $(=$ 밥통 $)(-0.28)$, 가위 $(=$ 부억가위 $)(-0.03)$, 가스레인지 $(=$ 가스렌지 $)(-0.23)$, 전자레인지 $(=$ 렌지 $)(0.07)$, 국그릇 $(=$ 국대접 $)(-0.27)$, 컵 $(0.02)$, 그릇 $(=$ 그릇세트 $)(-0.09)$, 수저 $(-0.26)$, 주전자 $(0.01)$, 냉장고 $(-0.05)$, 포크 $(0.40)$, 솥 $(=$ 솥단지 $)(0.40)$, 전기밥솥 $(=$ 전 기솥, 전기밥통, 전자밥솥)(-0.03), 집게 $(0.59)$, 뒤집개 $(=$ 뒤집기, 전뒤집기 $)(0.49)$, 쟁반 $(=$ 오봉 $)(0.33)$, 압력솥 $(=$ 압력밥솥 $)(0.04)$, 대접 $(0.10)$, 수세미 $(0.33)$, 믹서기 $(=$ 믹서 $)(0.69)$

\section{[학용품]}

연필 $(-0.54)$, 지우개 $(-0.43)$, 볼펜 $(-0.53)$, 공책 $(=$ 노트 $)(-0.51)$, 크레파스 $(=$ 크레용 $)(-0.11)$, 필통 $(-0.34)$, 만년필 $(-0.01)$, 색연필 $(-0.16)$, 자 $(-0.21)$, 칼 $(=$ 커터칼 $)(-0.11)$, 사인펜(-0.14), 가위 $(-0.26)$, 도화지(-0.17), 색종이 $(=$ 색지 $)(-0.01)$, 물감(=수채화물감, 그림물감 $)(0.16)$, 스케치북 $(0.02)$, 샤프 $(=$ 샤프펜슬 $)(-0.02)$, 풀 $(=$ 딱풀 $)(-0.18)$, 붓(0.29), 컴퍼스(0.28), 책받침(=공책받침)(0.06), 연필깎이(0.06), 매직(0.33), 삼각자(0.18), 종이(-0.24), 연습장 $(-0.14)$, 벼루(0.73), 형광펜(0.19), 먹 $(=$ 묵)(0.76), 잉크(0.61), 각도기(0.44)

\section{[채소]}

배추(-0.40), 무(-0.23), 시금치(-0.31), 상추(-0.39), 대파(=조선파, 파)(-0.33), 당근(-0.04), 양파(-0.26), 오이(-0.28), 고추(-0.26), 양배추(-0.05), 감자(-0.14), 쑥갓 (-0.03), 미나리(0.07), 마늘 $(=$ 통마늘 $)(-0.05)$, 부추 $(=$ 정구지 $)(-0.05)$, 고구마 $(0.23)$, 브로콜리 $(0.36)$, 토마토 $(0.34)$, 호박 $(-0.08)$, 콩나물 $(-0.17)$, 깻잎 $(-0.20)$, 도라지 (0.27), 가지(0.09), 피망(0.41), 고사리(0.30), 우엉(0.50), 열무(-0.07), 양상추(0.24), 파프리카(0.49), 쪽파(0.05)

\section{[전자제품]}

TV $(-0.62)$, 전자레인지 $(-0.42)$, 냉장고 $(-0.62)$, 세탁기(=삶는 세탁기) $(-0.47)$, 컴퓨터 $(=P C)(-0.31)$, 전기밥솥(=밥솥, 압력밥솥, 전기압력밥솥, 밥통) $(-0.51)$, 에어컨 $(=$ 벽걸이에어컨)(-0.34), 김치냉장고(-0.52), 휴대폰(=핸드폰, 스마트폰, 휴대전화)(-0.31), (앉은뱅이, 거실용, 탁상용)선풍기(-0.31), 라디오(0.04), (진공)청소기 $(-0.30)$, 전기주전자 $(=$ 전기포트, 커피포트 $)(0.07)$, 다리미 $(0.03)$, 드라이기 $(-0.07)$, (집)전화기 $(=$ 유선전화기 $)(-0.07)$, 믹서기 $(-0.04)$, 오디오 $(=$ 전축 $)(0.24)$, 전기오븐 $(=$ 오븐, 오븐레인지) $(-0.02)$, 비디오 $(=\mathrm{VTR})(0.40)$, 정수기 $(=$ 냉온수기 $)(0.23)$, 가습기 $(0.34)$, 온풍기 $(0.48)$, 전기난로 $(=$ 히터, 전기스토브, 전열기, 온열제품 $)(0.21)$, 전기 면도기 $(=$ 면도기 $)(0.32)$, 전기장판 $(=$ 전기매트 $)(0.00)$, 카메라 $(=$ 사진기 $)(0.51)$, 식기세척기 $(=$ 세척기 $)(0.46)$, 전기후라이팬 $(0.40)$, 전자시계 $(=$ 시계 $)(0.43)$, 냉동고 (0.10), 녹음기(0.65) 


\section{국문초록}

\section{5-74세 성인의 명사 범주 규준 조사}

김정완 ${ }^{1} \cdot$ 강연욱 ${ }^{2} \cdot$ 윤지혜 ${ }^{3}$

${ }^{1}$ 대구대학교 언어치료학과, ${ }^{2}$ 한림대학교 심리학과, ${ }^{3}$ 한림대학교 언어청각학부

배경 및 목적: 55-74세 성인의 명사 범주 규준(본보기 산출빈도와 전형성)을 조사하여 향후 신경언어장애 환자군의 이름대기 중재를 위한 치료자극 항목의 선정에 이용될 수 있는 기초자료로 활용하고자 한다. 방법: 정상 성인 401명이 연구에 참여하였다. 1단계(220명) 에서는 총 10 개 명사 범주(옷, 주방용품, 소지품, 채소, 가구, 교통수단, 학용품, 전자제품, 꽃, 동물)에 대한 생성이름대기를 각 1 분간 실 시하였다. 2 단계(216명)에서는 1단계에서 얻은 결과로 각 범주별 본보기의 평균 반응수와 본보기 종류의 총수를 산정한 후, 각 범주별 상위 30 위까지의 본보기들에 대한 의미전형성을 7점 척도로 평정하도록 하였다. 결과: 50-70대 성인들의 의미 네트워크는 범주 유창성 과제의 범주 목록에 따라, 그리고 연령 및 성별에 따라 변별적으로 달라짐을 확인할 수 있었다. 논의 및 결론: 연구 결과는 연령에 기초 한 의미 범주에 대한 정상규준 마련의 필요성을 보여준다. 본 연구는 향후 신경언어장애 환자군의 이름대기 중재 프로그램을 개발하는 데 있어 자극항목 선정 시 염두에 두어야 할 객관적인 기초자료를 제공하는 데 그 의의가 있다. 또한, 본 자료는 한국 성인의 의미적 구조 나 의미자질을 이용한 이름대기 중재 효과를 살펴보는 후속 연구의 기초를 제공한다.

핵심어: 이름대기, 노년층, 범주 규준, 본보기, 전형성

본 연구는 2014년 정부(교육부)의 재원으로 한국연구재단의 지원을 받아 수행된 연구임(NRF-2014S1A5A2A03065709).

\section{참고문헌}

강연욱(2006). K-MMSE (Korean-Mini Mental State Examination)의 노인 규준 연구. 한국심리학회지: 일반, 25, 1-12.

김정숙, 강수균(2005). 상위 범주화 훈련이 알츠하이머형 치매 환자의 이름대기에 미치는 효과. 난청과 언어장애, 28, 93-114.

김태희(2010). 장소 어휘를 중심으로 한 정상 성인의 생성이름대기. 연세대학교대학원 석사학위논문.

성지은, 모경옥, 이지선, 심현섭(2014). 노년층을 대상으로 한 명사 범주별 본보기 산출빈도, 의미전형성 및 친숙도 연구. 언어청각장애연구, 19, 213-

225.

이관용(1991). 우리말 범주규준조사: 본보기산출빈도, 전형성, 그리고 세부특징조사. 한국심리학회지: 실험 및 인지, 3, 131-160.

전덕임, 강연욱(2007). 초등학교 아동들의 우리말 범주 규준 조사. 언어청각장애연구, 12, 90-104.

정유진, 황유미, 홍정하(2014). 의미범주 지식의 다양성과 보편성: 동물 범주 유창성 과제를 활용하여. 담화와 인지, 21, 209-232. 